\title{
Architecture vs. nature: a reinvented relationship
}

\author{
P. Haupt \\ Cracow University of Technology, Poland
}

\begin{abstract}
Architectural and urban design are influenced by more and more restrictive legislative regulations which go along with the increasing awareness of the impact of human activities on the environment. This trend is stimulating the development of sustainable technologies applied in architecture. Incorporating elements of nature using their unique features supporting energy efficiency, airquality control, water and sewage management systems can often be observed. Elements of nature may be implemented in the building itself, as well as in its surroundings and interior. Therefore there may be a new type of space observed in contemporary sustainable structures - a transition space forming a soft edge between the building, its interiors and the city. The paper describes the relationship between architecture and nature; how it is being rediscovered by sustainable design and for architecture to become the substance for the new city tissue.
\end{abstract}

Keywords: sustainable design, green architecture, architecture vs. nature.

\section{Introduction}

Owing to the social awareness of the consequences of the uncontrollable growth of cities, the need for sustainable development has become obvious. Subsequent legislation changes aiming at incorporating sustainable solutions into the design of buildings have caused the image of contemporary built environment to change. Architects and urban planners are encouraged to implement sustainable design through legislative and economical demands. We witness the introduction of low carbon, alternative energy, eco innovative advanced water management systems, land decontaminating and reusing processes, improving social structure investments developed across Europe. Products of ecological agriculture are 
offered, even fashion collections became environmentally conscious. This trend has stimulated the development of sustainable technology applied in the built environment - public space, as well as buildings and their interiors. There is also the need emphasized not only to design rationally, but above all - use buildings and spaces wisely, thus the humane aspect of sustainable development is constantly gaining more and more importance. The combination of these two trends is reflected in the composition of today's common space - between the buildings, at the edge of the structure and its surrounding, as well as inside it, indicating the future direction in the ways of architectural and urban space arrangement.

\section{Nature: back to utility}

The sustainability pursuit results in the need for a new approach to the relationship between architecture and nature. The elements of the natural world, so far desired mainly due to their aesthetics, have now become useful elements, necessary for gaining energy, saving water, and improving air quality. However, they have not lost their aesthetic meaning. Natural elements have gained a new role of shaping development and public spaces and addressing new, unified perception of architectural and urban space.

At the beginning of the twentieth century a quest in search for a new character of the relation between architecture and nature began. In art and literature there was a rejection of a utilitarian role of nature observed. Thus the aesthetic impression of natural elements became essential for architecture, as an inspiration for ornament, form and background of the composition. Finally it took shape in the twentieth century, returning to its Vitruvian roots, being understood as "a network of relations between man and nature" instead of a whole in itself. Modernist architecture "tries to regain nature aesthetically - as landscape - changing a house into a 'dwelling machine”" (Lisak [1]). Postmodern period is characterized by understanding the elements of nature as pawns in a "game" serving the aestheticization of an open or urban landscape. A search for the essence of the relation between architecture and nature in contemporary man's domain - culture originated in the early nineteenth century. Contemporarily nature becomes a material for architecture and public spaces man's place of residence. Natural elements, understood as the building material for a housing environment, are not just a landscape - an aesthetical supplement to architecture - anymore. They are used practically as well.

\section{Architecture and nature}

Thinking cityscape, the first association is a landscape built of structures: a conglomerate of buildings of different use, scale, form, creating more or less regular urban structure. Through sustainable design this usual image might be inverted. The buildings are often hidden concealed the green roofs, hidden into the ground for more efficient insulation creating a new topography in the existing natural landscape. The example might be the London Grassroots community 
centre (Fig. 1). The design is innovative; the planted roof minimizes building's visual impact on the park's green space. The centre even offers a path network to allow visitors to circulate around and over the building. The structure reaches a maximum height of five metres, and the floor level is 0.8 metres beneath ground level with grassed landscaping to the sides and roof. On the southern elevation Grassroots has several full height windows which contribute to passive solar heating and lighting. They also offer wide views over the southern section of park, thereby greatly contributing to the sense of security for park users. Apart from sustainable technology the building was designed as a community centre for social contacts of the neighbourhood's society. Therefore it meets the ground rules for the green city worded by Brenda and Robert Vale: "A green architecture involves more than the individual building on its plot; it must encompass a sustainable form of urban environment. The city is far more than a collection of buildings; rather it can be seen as a series of interacting systems for living, working and playing - crystallized into built forms" (Vale and Vale [2]). The building is fully accessible to the mobility impaired, which emphasises its humane appearance.

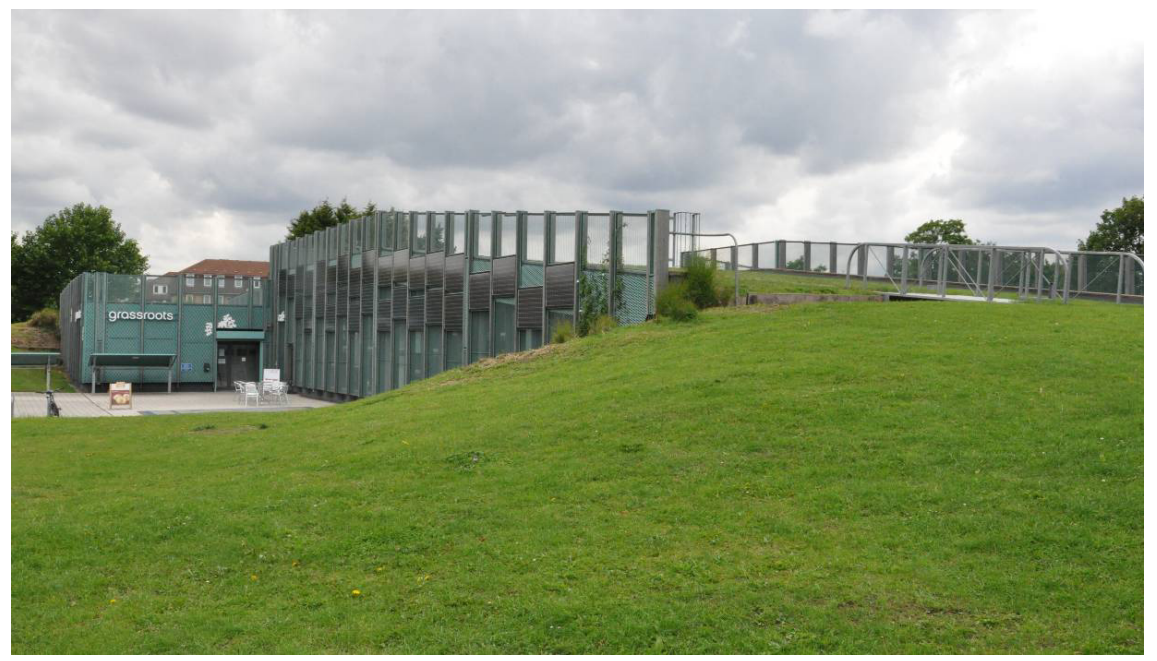

Figure 1: Grassroots Community Center, Eger Architects, London 2005, (photo: author P. Haupt, 2011).

The new topography as an outcome of sustainable architecture features might be created using natural landscape components, gaining the image that it was carved into the ground. On the other hand natural landscape may be used as an inspiration, imitating nature in an act of architectural creation that produces an artificial landscape, mimicking its diverse and complex form. This kind of concept derives from megastructural and cellular architecture from the 1950s. Within its design principles there were: "high variety of dwelling forms, flexibility of planning systems and originality and dynamism of architectural 
expression (...) seen at the time as an appropriate answer to the sociological and formal dilemmas" (Leśnikowski [3]). Centre Jeanne-Hachette or Cite du Parc the buildings by Nina Schuch representing this particular tendency, that have appeared in the 1970s in the Paris satellite town of Ivry-sur-Seine imitate natural terrain topography, and would probably nowadays be considered sustainable. Certain similarity might be found between the idea of designing non-repeatable individual units of flexible functionality connected into a biomorphic urban village and today's community system city. The large terrace gardens, green roofs are the features that served as prototypic to contemporary forms such as the multifamily residential and office building by Delugan and Meissl in Vienna (Fig. 2). In this case, not only the idea of sustainability understood as technology, but also the lifestyle and psychological factor was incorporated into the design. The Wimbergergasse Townhouse occupies a building gap that arose in the dense urban grid of Gründerzeit tenant houses [4]. The design displays two dominant motifs - the accentuation of topography and the space-containing feature of the façade. It also contributes to the reduction of transportation needs by creating space for home-offices.

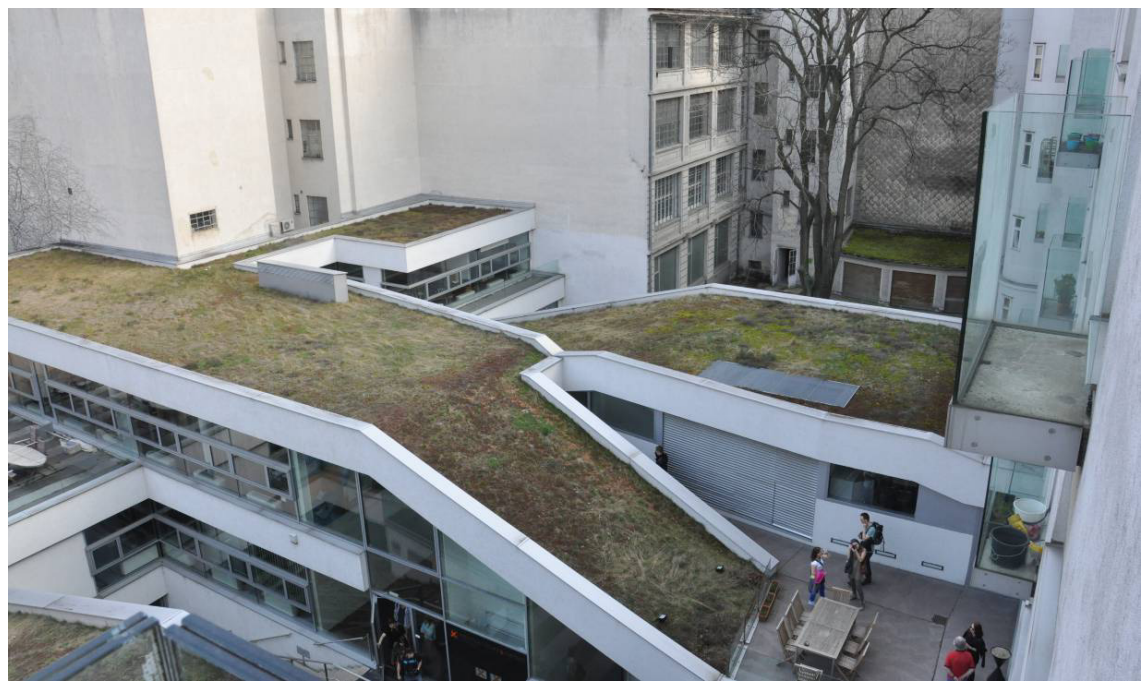

Figure 2: Wimbergergasse Townhouse, Delugan and Meissl, Vienna, 2001, (photo: P. Haupt, 2011).

At the same time the office part of the building not only provides technological features such as using green roofs as ecological insulation, but also it is shaped hilly-like to provide natural lighting to all 11 office spaces located there. Furthermore it offers multiple pleasant views on the courtyard over a green hilly roofscape serving as a passive recreational area [5]. This feature added an extra quality to the dense cityscape - a space that gives inhabitants a possibility to contact with nature which is crucial for human health. This quality might be considered one of the features of the new, people-friendly sustainability. 
Another example of similar - landscape creating approach might be the Mountain Dwellings raised in Copenhagen in 2008. It is considered an architectural attempt of counter reaction to the natural Danish monotonous lowlands landscape (Figs 3 and 4). The piling form of this multifamily residence complex designed by BIG Bjarke Ingels Group is a result of recognizing sustainable design postulates. Stacking housing units on top of artificial concrete mountain hiding multi-storey garage let not only for economic use of terrain; it also provided the possibility of locating two story apartment structure typical for suburban houses with the open ground floor façade facing south. Providing this solution the solar gains were maximized reducing both: heating energy and electric lighting energy demand. Apartments were stacked one on top of another preventing from shading. The green roof area provides the space for terrace and garden for the unit above, and it was designed to gather rainwater that is reused inside the building for gardening and housekeeping purposes. The structure as a whole forms an artificial hill covered with roof gardens facing the sun, concealing 650 parking lots. This solution encouraged inhabitants to use nearby recreation area along the canal by giving the priority to pedestrian traffic $[6,7]$.

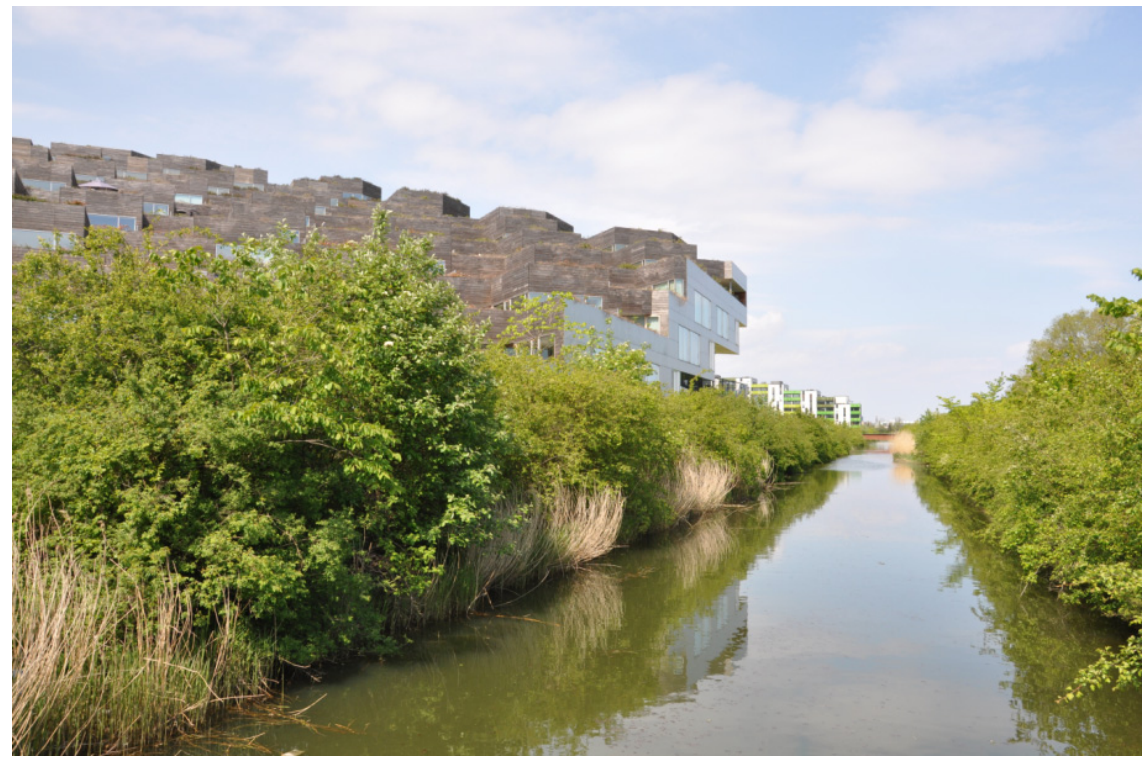

Figure 3: Mountain Dwelling, BIG, Copenhagen, 2008 (photo: P. Haupt, 2011). 


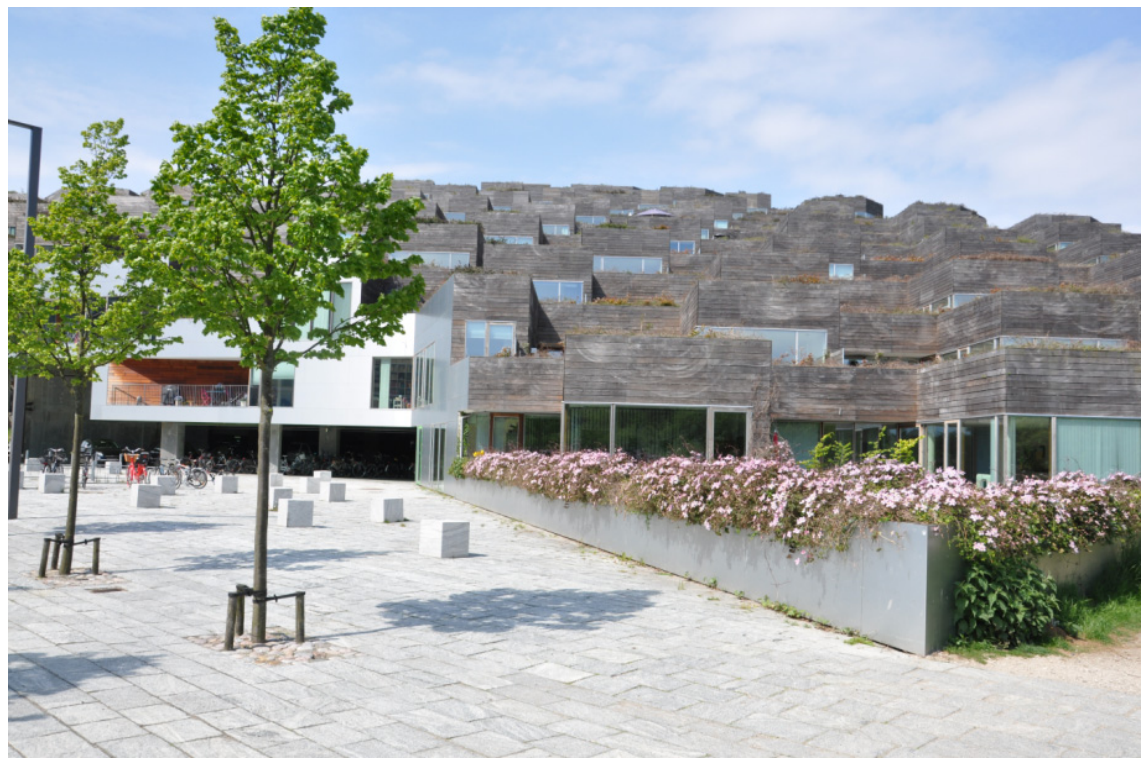

Figure 4: Mountain Dwelling, BIG, Copenhagen, 2008 (photo: P. Haupt, 2011).

\section{Common space: transition space}

Studies on creating healthy human built environment proved that the contact with nature is inevitable (Schneider-Skalska [8]). Spending long our in the interior sterile environment causes multiple physical as well as mental health conditions. On the other hand through the rapid development of communication technologies people lack the direct interpersonal contact. The answer to that problem may be encouraging the people to use exterior spaces to satisfy their recreation and social behaviour needs. The architecture nowadays seeks to provide a favourable environment to live, work, relax, thus providing a new aesthetic dimension, as well as contemporary social relationship between the user and his surrounding by restoring the relationship between man and nature. It might be compared to the human interrelationship with nature in Japanese architecture described by Tadao Ando: "This kind of sensibility has formed a culture that de-emphasizes the physical boundary between residence and surrounding nature and establishes instead a spiritual threshold. While screening man's dwelling from nature it attempts to draw nature inside" [9]. Therefore there may be a new type of space observed in contemporary sustainable structures - a transition space forming a soft edge between the building, its interiors and the city. Elements of nature may become the substance for creating that kind of space implemented in the building itself, as well as in its surroundings and interior. The 220,000 square meter pedestrian-oriented Linked Hybrid complex designed by Steven Holl may serve as example. It is located 
adjacent to the site of old city wall of Beijing. In contrast to the idea of closed, private urban space currently popular in China, Steven Holl has created the new quality - an area linked with its surrounding, inviting and open to all its users. The sequence of events in the Beijing complex is possible due to pedestrian access from all its sides inside. Urban common space; around, over and through multifaceted spatial layers, as well as the many passages through the project, make the Linked Hybrid an "open city within a city". The project promotes interactive relations between the residents and encourages encounters in the public spaces that vary from commercial, residential, and educational to recreational. Fused together exterior and interior spaces, both above and under the ground are places of interactive relationships [10]. The inner pedestrian ways form a loop that aspires to be more a grid-like rather than simplistically linear. The establishments for the design were to create one of the largest green residential structures in the world. It was made possible by the use of geothermal wells (655 at 100 meters deep) that provide Linked Hybrid with cooling in summer and heating in winter. The narrative path of the object is supplemented with the symbolic shaping of its green spaces. The earth excavated from under the Linked Hybrid served as substance for shaping five mounds forming the park surrounding the complex. Each of them corresponds to one stage of human life. Architecture, a city and "a non-city" are combined in the infinite system of meanings, created by their users. Without any special procedure a common, homogeneous space is created - the space of "equal opportunities" [11].

\section{Human scale: soft edge}

Our existence in society is the contact with the space filled with matter animated such as elements of nature and other men, and inanimate - architecture. Space itself becomes meaningless, just as the sum of two components: nature along with man as a part of it and architecture, it gains its appearance, impression. The process of space occurrence results in the reciprocal formatting of man, nature and architecture, and this relationship is like a symbiosis between two species of organisms. From the point of view of developmental psychology, the being of man is defined as an active existence, filled with movement, development, operation while passiveness is predestined to stagnation, regression and stillness [12]. Man, as a living organism is characterized by continuous change of position in relation to the space in which it is located. Constantly moving, we need variable amounts and qualities of space [13]. Moreover, human activity manifests itself in the activities performed by man in the space continuously transforming provided by architecture and nature.

Professor Jan Gehl describes the image of urban spaces in the twentiethcentury European cities. The title of his book "Life between Buildings" indicates that the city nowadays became the basic environment for human species [4]. Therefore it is crucial to look at the built environment from the perspective of a human scale which he introduces in his next piece "Human Scale". Finally in his latest book "Cities for people" he encourages architects and planners to take a 
more systematic approach and take these "cities for people" more seriously and then we will find that the cities would be considerably more friendly, livable, and lively because people will be in these cities more [14]. He stresses that townscape public space will become more attractive, more frequently used and in conclusion more sustainable, with the support of public transportation, because there will be more natural activity built into the day. As one of the main design issues he states that forming soft edges between buildings and their surroundings would be vital to create a successful connected city public space. One of the means of creating such a transition space is using natural elements, and landscape overviews, in composition of urban enclosures and architectural interiors that would form a common space path for the user to move in and out of the structure. Those tendencies were visible in the composition of open-access architectural spaces with a different intended use, which can be exemplified by the Swiss Re building (BRT Architekten, 2001) in Munich or the Rolex Learning Center (SANAA group) in Lausanne. Those structures may point toward an inspiration for the built environment of the XXI century.

\section{Summary}

Architecture through the modern way of interacting with nature, regains its lost aesthetic dimension that it had in the past. The city can be perceived as a conglomerate of buildings that form the landscape. The harmony with natural elements visible in public spaces seems to penetrate into the interiors, creating a kind of elaborate entrance area that blurs the boundary between the building and its neighbourhood. The introduction of sustainable solutions in the composition of buildings and urban design does not only challenge the designers, moreover it enriches their projects by creating a new kind environment - transition space. Through the use of natural elements for viewports, thresholds and projections a new quality is achieved - especially noticeable in public space that is according to Jan Gehl the very nature of the city.

\section{References}

[1] Lisak A., Natura a architektura - filozoficzne postawienie problemu, Architektura współczesna wobec natury, red. L. Nyka, Gdańsk 2002, p. 17.

[2] Vale B., Vale R., Green Architecture: Design for a Sustainable Future, London 1991, p. 169.

[3] W. Leśnikowski, Nina Schuch: Architecture of the Diagonales, Architektura \& Biznes 1997 No 1, pp. 24-25.

[4] Housing in Vienna. Innovative, Social and Ecological, ed. W. Förster, Vienna 2008.

[5] Delugan and Meissl webpage: http://www.dmaa.at/projekte/detailpage/townhouse-wimbergergasse.html [accessed: 29.03.2013].

[6] Mountain, red. Danish Architecture Center, http://www.dac.dk/en/daclife/copenhagen-X-gallery/cases/mountain/ [accessed: 2.12.2013]. 
[7] Levitt J., Urban Green: The Mountain Dwellings by Bjarke Ingels Group http://www.worldchanging.com/archives/011183.html [accessed: 2.12.2013].

[8] Schneider-Skalska G., Kształtowanie zdrowego środowiska mieszkaniowego (Creating healthy housing environment), Kraków, 2004.

[9] Tadao Ando, ed. Harriet Schoenholz Bee, New York 1991, p. 75.

[10] Linked Hybrid, http://www.stevenholl.com/project-detail.php?id=58

[11] Martha Schwartz Partners, http://www.marthaschwartz.com/projects/ corporate_swissre.php

[12] Visions of the Future, Architecture for the 21st Century, red. M. Serrats, Barcelona 2011, p. 6.

[13] Hall E.T., Ukryty wymiar, Warszawskie Wydawnictwo Literackie Muza SA, Warszawa 2003, p. 84.

[14] Interview with Jan Gehl, American society of landscape architects, access: 01.02.2014, http://www.asla.org/ContentDetail.aspx?id=31346 